\title{
COLORIMETRIC AND VISUAL EVALUATION OF SARCOSINE IN THE ARTIFICIAL URINE
}

\author{
'Zuzana TOTHOVA, 'Dagmar UHLIROVA, 'Martina STANKOVA, ${ }^{1}$ Michaela VSETICKOVA, \\ ${ }^{2}$ Branislav RUTTKAY-NEDECKY, ${ }^{3}$ Marta KEPINSKA, ${ }^{1} \mathrm{~J}$ osef RUZICKA, ${ }^{3}$ Halina MILNEROWICZ, \\ ${ }^{4}$ Warawan EIAMPHUNGPORN, ${ }^{1,2,3}$ Rene KIZEK \\ ${ }^{1}$ Department of Research and Development, Prevention Medicals s.r.o., Studénka-Butovice, \\ Czech Republic, EU, uhlirova@preventionmedicals.cz \\ ${ }^{2}$ Department of Human Pharmacology and Toxicology, University of Veterinary and Pharmaceutical \\ Sciences Brno, Czech Republic, EU, kizek@sci.muni.cz \\ ${ }^{3}$ Department of Biomedical and Environmental Analyses, Faculty of Pharmacy with Division of Laboratory \\ Diagnostics, Wroclaw Medical University, Wroclaw, Poland, EU, zalewska.m@gmail.com \\ ${ }^{4}$ Department of Clinical Microbiology and Applied Technology, Faculty of Medical Technology, Mahidol \\ University, Salaya, Nakhon Pathom, Thailand
}

https://doi.org/10.37904/nanocon.2019.8516

\begin{abstract}
Suitable molecular or biochemical markers are sought for rapid diagnostics of cancer. A very promising candidate is the sarcosine (SAR) amino acid, which is elevated in the urine of the patients with prostate cancer. The aim of this work was to develop a simple, fast and reliable method for SAR detection in human urine. Sarcosine oxidase hydrolyses sarcosine and the resulting peroxide is converted to a colored product. By colorimetric analysis, sarcosine could be detected at low concentrations, limit of detection (LOD) was $1 \mu \mathrm{M}$ and limit of quantification (LOQ) was $6 \mu \mathrm{M}$ in artificial urine. As a quick test for the presence of sarcosine in urine, a visual assessment of color change has been proposed. Visual results were evaluated as RGB signal densities. The obtained results show that the average RGB variability between test samples was about $10 \%$. From these values, the ROC curve of the individual experiments was determined. Sensitivity (from 0.59 to 0.83 ) and specificity (1.00) were calculated using ROC curves according to the type of artificial urine. ROC curves were more than $25 \%$ rated as excellent, $65 \%$ as very good from $5 \%$ as good and none as unsatisfactory. Conclusion: Colorimetric detection of sarcosine in urine was sensitive. Visual evaluation of the test showed $100 \%$ success in identifying the presence of sarcosine in artificial urine. The obtained data show the potential of the method for the visual evaluation of the presence of sarcosine in the urine and its possible use in the diagnostics of prostate cancer.
\end{abstract}

Keywords: Sarcosine, malignant prostate tumors, biosensor, colorimetric detection, visual test

\section{INTRODUCTION}

Prostate cancer is the most common malignancy in men [1-3]. According to WHO statistics, more than 1.1 million new cases are diagnosed worldwide each year and about 307,000 deaths are recorded. In Europe, about 190,000 newly diagnosed cases and 80,000 deaths are recorded each year [1]. The incidence of prostate cancer varies significantly geographically and increases with age [1]. Suitable tumor markers are sought for rapid diagnostics [4-7]. A very promising biochemical candidate is the amino acid sarcosine $(\mathrm{N}$ methylglycine) $[8,9]$. Sarcosine is an amino acid that is part of the glycine, serine, and threonine pathways. Sarcosine may be formed by glycine methylation by the action of the glycine $\mathrm{N}$-methyltransferase (EC 2.1.1.20). In a number of studies it has been found that the amount of sarcosine in the blood is in units of micromolar concentrations [10,11]. For some diseases such as sarkosinemia and glutaric aciduria type II occur sarcosine elevated levels in blood and urine [11]. Sarcosinemia is a very rare metabolic disorder that does not have precisely defined clinical manifestations. In this disease, sarcosine levels increase in both urine and blood 
plasma [11]. The analyzed sarcosine values in these cases can range from tens to hundreds of micromolar concentrations. The stated biological relevance of sarcosine is significant, so it is important to seek appropriate techniques for its rapid and reliable detection. A variety of analytical techniques are used to detect sarcosine: photometry, electrochemistry, mass detection, and liquid chromatography [12-17]. These techniques allow the determination of the amino acid selectively and highly sensitively [18]. Enzymatic methods are well suited for automated determination of creatinine, uric acid, triacylglycerol, cholesterol, glucose and possibly other analytes utilizing Trinder reaction [19]. This reaction is based on the use of a suitable dye (such as aminoantipyrine and other suitable molecules) in the presence of hydrogen peroxide and peroxidase. The reaction produces a quinonimine dye which is photometrically evaluated (Figure 1). Introducing of this reaction to clinical biochemistry has, in conjunction with substrate-specific enzymes, brought about a significant improvement in specificity and selectivity [20]. Nanomedical approaches brings technology with high sensitivity, specificity and significantly lower operating costs and are applicable for the analysis of biomolecules $[2,21,22]$.
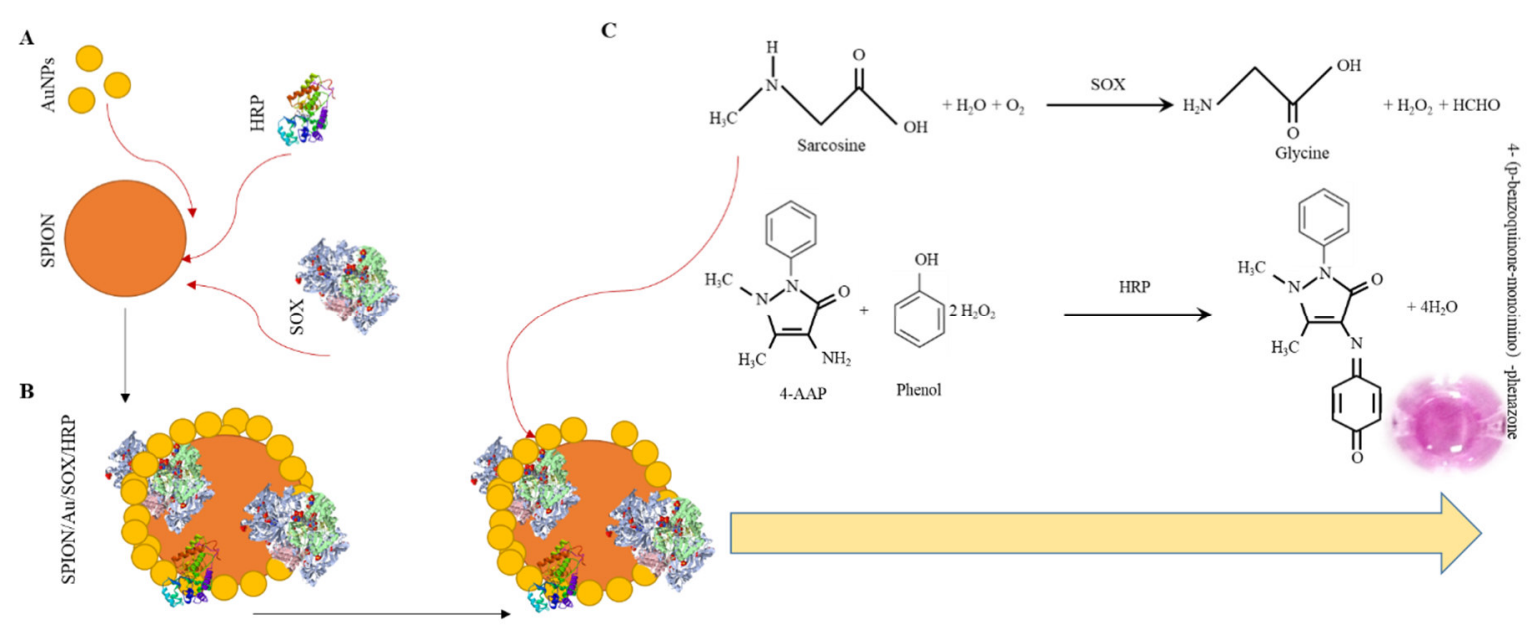

Figure 1 Schema of colorimetric sarcosine detection. (A) SPION nanoparticles for detection of sarcosine are modified by addition AuNPs, HRP and SOX in polymeric netting with chitosan. Modified SPION/Au/SOX/HRP particles (B). SPION/Au/SOX/HRP particles together with sarcosine and 4-AAP generates colorful product.

\section{MATERIAL AND METHODS}

Colorimetric evaluation: Measurements were performed on a UV-3100 PC spectrophotometer (VWR, USA). Plastic cuvettes (UV-VIS, BRAND, USA) were used for the measurements. $500 \mu$ reagent was pipetted into the cuvette followed by $100 \mu \mathrm{l}$ of sample. The reaction solution was used as the blank. Spectrophotometric measurements were also performed on a polystyrene microtiter plate, which was previously washed with 18 $\mathrm{M} \Omega$ water ( 3 times, $300 \mu \mathrm{l})$ at room temperature using a reader (TECAN, Switzerland). $50 \mu \mathrm{l}$ of sample and $250 \mu \mathrm{l}$ of reagent were pipetted into the well of the plate. Absorbances were measured every $1 \mathrm{~min}$ at $540 \mathrm{~nm}$ for a total time of $60 \mathrm{~min}$.

Visual assessment: glass vial - contains gold magnetic nanoparticles with bound enzymes. The total vial volume is $1000 \mu \mathrm{l}$. The reaction solution contains components for the color visualization of the sarcosine presence. The color reaction was evaluated visually and statistically processed in the Laboratory information system (color vial - positive; colorless vial - negative).

Reaction solution: contained 4-AAP (4-aminoantipyrine), sarcosine oxidase, horseradish peroxidase in $0.2 \mathrm{M}$ phosphate buffer $(\mathrm{pH} 8)$. After pipetting the sample into the reaction solution, incubation was performed for 30 minutes. 
Test Samples: Urine samples (15 types) were prepared according to available protocols [23-25].

\section{RESULTS AND DISUSSION}

\section{Principle of colorimetric evaluation of sarcosinuria}

Amino acids are colorless and their direct photometric determination is difficult. A suitable option for amino acid analysis is to react with a chromophore to form color complexes [26]. Sarcosine oxidase is a specific enzyme that hydrolyses only the sarcosine amino acid to glycine to form by-products of hydrogen peroxide and formaldehyde. Subsequently, the resulting hydrogen peroxide can be determined using the Trinder reaction $[3,20]$. Phenol reacts with hydrogen peroxide and 4-aminoantipyrine under peroxidase catalysis to produce 4- ( $p$-benzoquinone-monoimino) -phenazone detectable spectrophotometrically at $510 \mathrm{~nm}$. The composition of the natural urine is very variable and contains a variety of waste metabolites, drugs and other interferents. Artificial urine is a suitable matrix for studying changes in SOX activity. SOX activity $(1 \mathrm{U} / \mathrm{ml})$ was observed as sarcosine hydrolysis (60 $\mathrm{min}, 125 \mu \mathrm{M}$ sarcosine). The limit concentration is very well distinguishable from the negative result ( $L O D=1 \mu \mathrm{M}, \mathrm{LOQ}=6 \mu \mathrm{M}, \mathrm{RSD}=15 \%)$. When this condition was met, the test was visually evaluated in detail. The basic parameter of the test suitability indicator is the evaluation of ROC curves and thus the specificity and sensitivity of the test. Test series were prepared $(n=5)$, where urine samples were loaded onto microtiter plate. Artificial urine was enriched with several concentrations of sarcosine $(216,166,125,62.5,31.2,15.6$ and $0 \mu \mathrm{M})$. Subsequently, the reaction solution was added and the color reaction was developed for $30 \mathrm{~min}$. Subsequently, each series of samples (15 types of artificial urine, 12 repetitions) was photographically captured and subsequently visually evaluated. Each test performed was evaluated in independent replicates $(n=5)$. Individual results were labeled as true positive, false negative, or true negative. The results of the evaluation were processed statistically by the ROC curve evaluation method (at a level of $95 \%$ ).

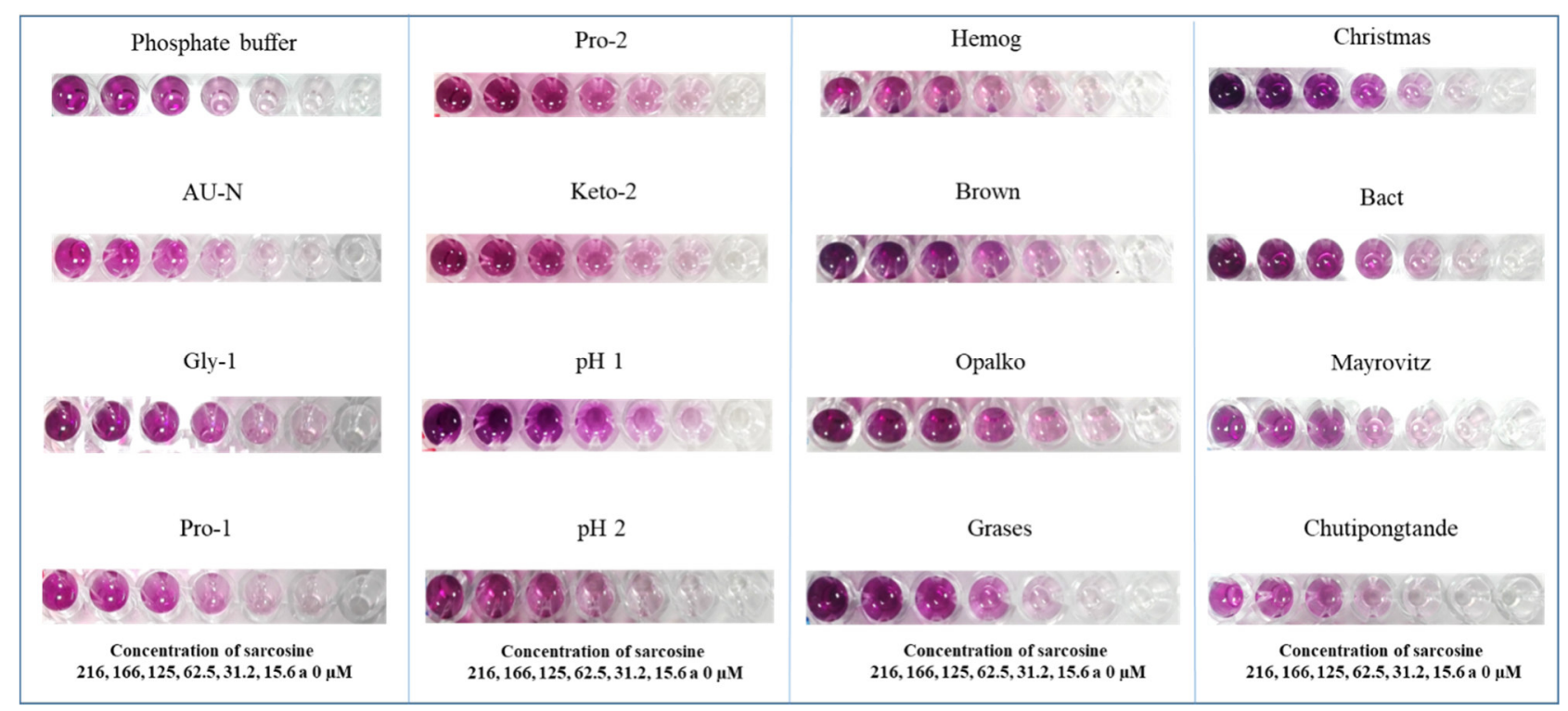

Figure 2 Typical image visual test for present of sarcosine in different type of modified human urines (fosfate buffer - control, AU-N, Gly-1, Pro-1, Pro-2, Keto-2, pH 1, pH 2, Hemog, Brown, Opalko, Grases, Christmas, Bact, Mayrowitz, Chutipongtande). Concentrations of sarcosine are 216, 166, 125, 62.5, 31.2, 15.6 and 0 $\mu \mathrm{M}$. Result of color reaction after 30 minutes. Photo made by Canon $10 \mathrm{Mpx}$. All image were evaluated.

Another details are in the part of Material and Metods. 
The principle of visual evaluation of sarcosinuria. The test was performed with sarcosine additions (216, $166,125,62.5,31.2,15.6$ and $0 \mu \mathrm{M}$ ) at room temperature for $30 \mathrm{~min}$. The resulting color reaction was recorded photographically. Individual images were visually evaluated. Each sample was assessed for whether or not it provided a color reaction. LOD was determined as the concentration of sarcosine in the urine that could be visually recognized. All obtained data were subsequently mathematically evaluated. The ROC curve of the individual experiments was determined $(n=5)$. Sensitivity from 0.78 to 1.00 and specificity 1.00 was calculated using ROC curves according to the type of artificial urine. ROC curves were more than $25 \%$ rated as excellent, $45 \%$ outstanding, $20 \%$ very good, less than $5 \%$ good and none as unsatisfactory.

\section{CONCLUSION}

A sarcosine amino acid stability assay was performed using an enzymatic reaction. Sarcosinuria was evaluated colorimetrically and visually. A $100 \%$ success rate for the identification of sarcosine was confirmed from the statistical evaluation of the ROC curves. The data obtained indicate the potential of the method for visual assessment of the presence of sarcosine in urine. The visual test for detection of sarcosinuria is designed for ease to use. The average user should be able to perform and evaluate the result. The steps, including the evaluation, do not exceed 45 minutes.

\section{ACKNOWLEDGEMENTS}

\section{The work was supported by the SARKOTEST 165/2015 project and the European Technology Platform for Nanomedicine.}

\section{REFERENCES}

[1] BARBIERI, C. E., CHINNAIYAN, A. M., LERNER, S. P., SWANTON, C., RUBIN, M. A. The Emergence of Precision Urologic Oncology: A Collaborative Review on Biomarker-driven Therapeutics. Eur. Urol., 2017, vol. 71, no. 2, pp. 237-246.

[2] ALTWAIJRY, N., SOMANI, S., DUFES, C. Targeted nonviral gene therapy in prostate cancer. Int. J. Nanomed., 2018, vol. 13, no. pp. 5753-5767.

[3] TRINDER, P. Determination of blood glucose using 4-amino phenazone as oxygen acceptor. J. Clin. Pathol., 1969, vol. 22, no. 2, pp.

[4] SAWYERS, C. L. The cancer biomarker problem. Nature, 2008, vol. 452, no. 7187, pp. 548-552.

[5] GIL, J., RAMIREZ-TORRES, A., ENCARNACION-GUEVARA, S. Lysine acetylation and cancer: A proteomics perspective. J. Proteomics, 2017, vol. 150, no. pp. 297-309.

[6] MAURER, T., EIBER, M. Practice changing for prostate cancer: a vision of the future. Nat. Rev. Urol., 2019, vol. 16, no. 2, pp. 71-72.

[7] HEITZER, E., HAQUE, I. S., ROBERTS, C. E. S., SPEICHER, M. R. Current and future perspectives of liquid biopsies in genomics-driven oncology. Nat. Rev. Genetics, 2019, vol. 20, no. 2, pp. 71-88.

[8] SREEKUMAR, A., POISSON, L. M., RAJENDIRAN, T. M., KHAN, A. P., CAO, Q., YU, J. D., LAXMAN, B., MEHRA, R., LONIGRO, R. J., LI, Y., NYATI, M. K., AHSAN, A., KALYANA-SUNDARAM, S., HAN, B., CAO, X. H., BYUN, J., OMENN, G. S., GHOSH, D., PENNATHUR, S., ALEXANDER, D. C., BERGER, A., SHUSTER, J. R., WEI, J. T., VARAMBALLY, S., BEECHER, C.,CHINNAIYAN, A. M. Metabolomic profiles delineate potential role for sarcosine in prostate cancer progression. Nature, 2009, vol. 457, no. 7231, pp. 910-914.

[9] CERNEI, N., HEGER, Z., GUMULEC, J., ZITKA, O., MASARIK, M., BABULA, P., ECKSCHLAGER, T., STIBOROVA, M., KIZEK, R., ADAM, V. Sarcosine as a potential prostate cancer biomarker--a review. Int. J. Mol. Sci., 2013, vol. 14, no. 7, pp. 13893-908.

[10] GKOTSOS, G., VIRGILIOU, C., LAGOUDAKI, I., SARDELI, C., RAIKOS, N., THEODORIDIS, G., DIMITRIADIS, G. The Role of Sarcosine, Uracil, and Kynurenic Acid Metabolism in Urine for Diagnosis and Progression Monitoring of Prostate Cancer. Metabolites, 2017, vol. 7, no. 1, pp. 14. 
[11] LEE, S. Y., CHAN, K. Y., CHAN, A. Y. W., LAI, C. K. A report of two families with sarcosinaemia in Hong Kong and revisiting the pathogenetic potential of hypersarcosinaemia. Annal. Acad. Med. Singapore, 2006, vol. 35, no. 8, pp. 582-584.

[12] CERNEI, N., ZITKA, O., RYVOLOVA, M., ADAM, V., MASARIK, M., HUBALEK, J., KIZEK, R. Spectrometric and Electrochemical Analysis of Sarcosine as a Potential Prostate Carcinoma Marker. Int. J. Electrochem. Sci., 2012, vol. 7, no. 5, pp. 4286-4301.

[13] BAI, C. J., LU, Z. W., JIANG, H., YANG, Z. H., LIU, X. M., DING, H. M., LI, H., DONG, J., HUANG, A. X., FANG, T., JIANG, Y. Q., ZHU, L. L., LOU, X. H., LI, S. H.,SHAO, N. S. Aptamer selection and application in multivalent binding-based electrical impedance detection of inactivated H1N1 virus. Biosensors \& Bioelectronics, 2018, vol. 110, no. pp. 162-167.

[14] NARWAL, V., KUMAR, P., JOON, P., PUNDIR, C. S. Fabrication of an amperometric sarcosine biosensor based on sarcosine oxidase/chitosan/CuNPs/c-MWCNT/Au electrode for detection of prostate cancer. Enzym. Microb.I Technol., 2018, vol. 113, no. pp. 44-51.

[15] KUMAR, P., JAIWAL, R., PUNDIR, C. S. An improved amperometric creatinine biosensor based on nanoparticles of creatininase, creatinase and sarcosine oxidase. Anal. Biochem., 2017, vol. 537, no. pp. 41-49.

[16] JOSYPCUK, O., BAREK, J., JOSYPCUK, B. Construction and Application of Flow Enzymatic Biosensor Based of Silver Solid Amalgam Electrode for Determination of Sarcosine. Electroanalysis, 2015, vol. 27, no. 11, pp. 25592566.

[17] GONZALEZ-SOLINO, C., DI LORENZO, M. Enzymatic Fuel Cells: Towards Self-Powered Implantable and Wearable Diagnostics. Biosensors-Basel, 2018, vol. 8, no. 1, pp. 18.

[18] SAMANTA, S., RAHAMAN, S. Z., ROY, A., JANA, S., CHAKRABARTI, S., PANJA, R., ROY, S., DUTTA, M., GINNARAM, S., PRAKASH, A., MAIKAP, S., CHENG, H. M., TSAI, L. N., QIU, J. T.,RAY, S. K. Understanding of multi-level resistive switching mechanism in $\mathrm{GeOx}$ through redox reaction in $\mathrm{H} 2 \mathrm{O} 2 /$ sarcosine prostate cancer biomarker detection. Sci Rep., 2017, vol. 7, no. pp. 12.

[19] UHLIROVA, D., STANKOVA, M., DOCEKALOVA, M., HOSNEDLOVA, B., KEPINSKA, M., RUTTKAY-NEDECKY, B., RUZICKA, J., FERNANDEZ, C., MILNEROWICZ, H., KIZEK, R. A Rapid Method for the Detection of Sarcosine Using SPIONs/Au/CS/SOX/NPs for Prostate Cancer Sensing. Int. J. Mol. Sci., 2018, vol. 19, no. 12, pp. 29.

[20] WIEWIORKA, O., DASTYCH, M., CERMAKOVA, Z. Trinderova reakce v klinické biochemii - přínosy a limity. Chem. Listy, 2017, vol. 111, no. 3, pp. 186-191.

[21] LAN, J. M., XU, W. M., WAN, Q. P., ZHANG, X., LIN, J., CHEN, J. H., CHEN, J. Z. Colorimetric determination of sarcosine in urine samples of prostatic carcinoma by mimic enzyme palladium nanoparticles. Anal. Chim. Acta, 2014, vol. 825, no. pp. 63-68.

[22] REBElO, T., PEREIRA, C. M., SALES, M. G. F., NORONHA, J. P., COSTA-RODRIGUES, J., SILVA, F., FERNANDES, M. H. Sarcosine oxidase composite screen-printed electrode for sarcosine determination in biological samples. Anal. Chim. Acta, 2014, vol. 850, no. pp. 26-32.

[23] PIETRZYNSKA, M., VOELKEL, A. Stability of simulated body fluids such as blood plasma, artificial urine and artificial saliva. Microchem. J., 2017, vol. 134, no. pp. 197-201.

[24] CHUTIPONGTANATE, S., THONGBOONKERD, V. Systematic comparisons of artificial urine formulas for in vitro cellular study. Anal. Biochem., 2010, vol. 402, no. 1, pp. 110-112.

[25] SHMAEFSKY, B. R. ARTIFICIAL URINE FOR LABORATORY TESTING. Amer. Biol. Teacher, 1990, vol. 52, no. 3, pp. 170-172.

[26] YAMKAMON, V., PHAKDEE, B., YAINOY, S., SUKSRICHAWALIT, T., TATANANDANA, T., SANGKUM, P., EIAMPHUNGPORN, W. Development of sarcosine quantification in urine based on enzyme-coupled colorimetric method for prostate cancer diagnosis. Excli Journal, 2018, vol. 17, no. pp. 467-478. 